Sri Lanka J. Aquat. Sci. 14 (2009): 45-57

\title{
Impact of women involvement in fisheries on socio-economics of fisher households in Negombo, Sri Lanka
}

\author{
D.M.P.R. DISSANAYAKA and M.J.S. WIJEYARATNE* \\ Department of Zoology, University of Kelaniya, Kelaniya, Sri Lanka \\ *Corresponding author (E-mail: zoomjs@kln.ac.lk)
}

\begin{abstract}
The socio-economics of the households in Wellaweediya fishing village in Negombo, Sri Lanka were studied in relation to women involvement in fisheries. No women in the village were engaged in preharvest activities and catching fish. Of the women involved in fisheries, about $50 \%$ were involved in fish processing activities such as gutting, salting and sun-drying. Those who were involved in gutting of fish earned about Rs. 300.00 for working for 6 hours per day while those who were engaged in salting and sun-drying were paid only Rs. 200.00 for working for about 12 hours per day. About $31 \%$ were involved in marketing the catch. By working for about $3 \frac{1}{2}$ hours per day, they earned Rs. 200.00 - 700.00. About $13 \%$ were involved in removing fish from small meshed gill nets and they were paid about Rs. 100.00 for working for 2 hours per day. The balance $6 \%$ were involved in collecting fish in to transportation baskets and for working for about 2 hours they were paid Rs. 100.00 if the catch was good and Rs. 50.00 if the catch was poor. The women labour of those involved in salting and drying and collecting fish into transportation baskets were found to be exploited with gender discrimination. The mean monthly income of the households where women were involved in fisheries was about Rs. 9350.00, which was about twice of the income of the households where women were not involved in fisheries. Most of the women involved in fisheries could not write and/or read and spent a more traditional way of life. Husbands of most of them were regular consumers of liquor. These women have not changed their gender based household division of labour and carried out activities such as cooking, washing, taking care of children etc.
\end{abstract}

\section{Introduction}

Women are engaged in wide variety of activities in fisheries throughout the world (ICSF 2009). These include pre- and post-harvest activities as well as actively catching fish. The pre-harvest activities include 
some skilled and time consuming jobs that take place on shore such as net mending and net preparation (FAO 2009). In addition, women help in carrying nets and other fishing gear to the shore (Williams et al. 2002, FAO 2009). When catching fish, most of the time they use small implements wading and gleaning the shores and lagoons for shellfish and sea weeds (FAO 2009). Sometimes they serve as crew members and also own fishing vessels (Williams et al. 2002, Saison et al. 2002, EC 2003, Viravongsa 2004). The post-harvest activities that women are involved include processing the catch and marketing it (EC 2003, FAO 2009). Many women serve as workers in sea food processing plants (EC 2003, ICSF 2009). Other postharvest activities that women are involved include fish sorting, icing, packing, loading fish into transport vehicles, smoking and drying (Williams et al. 2002, FAO 2009). When marketing the catch, women vendors are capable of maintaining secured buyers and establishing marketing networks (FAO 2009).

Women in many countries are involved in aquaculture and inland capture fisheries (Kusakabe and Kelkar 2001, FAO 2009). Sometimes, women of fisher families work in non-fisheries sector and earn supplementary income for their families (Sverdrup-Jensen 2002).

Many women engaged in fisheries have organized themselves into various societies and are members of fish worker movements and fishers organizations (EC 2003, ICSF 2009).

Women contribute to the fisheries sector also by developing knowledge on fisheries through research and imparting knowledge through teaching (EC 2003). As such, they help in addressing the global problem of food security (Saison et al. 2002, Williams et al. 2002).

While directly involved in fishery related activities, women continue to take care of the family and maintain social networks and culture of the community. They have not changed the gender based household division of labour even with the diversification of physical, economic and social environments and circumstances. Due to their economic contribution, they play a vital role at all levels of the fishery chain (ICSF 2009).

However, women's role in fisheries appears to be largely invisible and unacknowledged (Sivoi 2006, ICSF 2009). Although women make up the majority of work force in fish processing plants, they are mainly involved in low grade unskilled jobs. They are largely unwelcome in marine capture fisheries also (EC 2003). Usually women from poor fisher households are involved in fishery related activities. Women also lack opportunities to hold managerial and decision making positions in many occasions (Saison et al. 2002).

It has been estimated that more than 50 million women are engaged in fisheries throughout the world (Sothirak 2002). In the recent past, women involvement in fisheries has received much attention of researchers (Kyprianau 2001, Williams et al. 2002, FAO 2009). Women are involved in fish sorting, gutting fish and fish processing in many coastal areas of Sri Lanka. Sometimes they help their husbands to drag boats ashore. Women in 
the northwestern region of Sri Lanka are involved in beach seining and some women in that area own beach seines and boats (Saison et al. 2002). Women are also involved in wholesale and retail marketing of fish throughout the island. Sometimes they supervise the marketing of catch. Although the fishery related activities that women carry out in Sri Lanka are documented (Saison et al. 2002), their role in fisheries has not been studied in detail. Therefore, the present study was carried out to investigate the impact of involvement of women in fisheries on the socio-economics of fisher households in a coastal fishing community in Sri Lanka.

\section{Materials and Methods}

The present study was carried out from $1^{\text {st }}$ June to $30^{\text {th }}$ September 2004 in Wellaweediya fishing village $\left(7^{0} 12^{\prime} \mathrm{N} ; 79^{0} 51^{\prime} \mathrm{E}\right)$ in Negombo in the west coast of Sri Lanka. This village was selected after a preliminary survey as there were a considerable number of families where women were involved in fishery related activities as well as many families where women were not involved in fisheries. The list of households of the village was obtained from the relevant Government office (Grama Seva Niladhari office) and based on the information gathered during the preliminary survey, these families were separated into two categories, i.e., the families where women were involved in fisheries and the families where women were not involved in fisheries. Fifty households from each category were then selected at random and the information was collected by interviewing the family members using a structured questionnaire (Annex I). The families of boat owners who employ crew members were excluded from the study as the women in all such families were not involved in fisheries. Only the families of small scale fishers who fish in the Negombo estuary or coastal marine waters and involve in other fishery related activities such as marketing and processing the catch were included in the study.

The information gathered include the fishery related activities carried out by women, income of the family, religion, ability of women to write and/or read, level of education of children, nature of the house, availability of electricity and pipe-borne water, type of fuel used for cooking, consumption of liquor by the husbands, and the ancestral fishing background of women. The results were analyzed using student's t-test, Karl Pearson's Chi square test with Yate's correction (Zar 1995) and Kolmogorov-Smirnov test (Maway 1951) where appropriate.

\section{Results}

\section{Fishery related activities carried out by women}

The women in the study area were not involved in pre-harvest activities such as net mending and net preparation as well as catching fish. However, they were engaged in many post-harvest activities including 
removing fish from small meshed gill-nets, collecting fish into baskets, fish processing and marketing the catch (Figure 1).

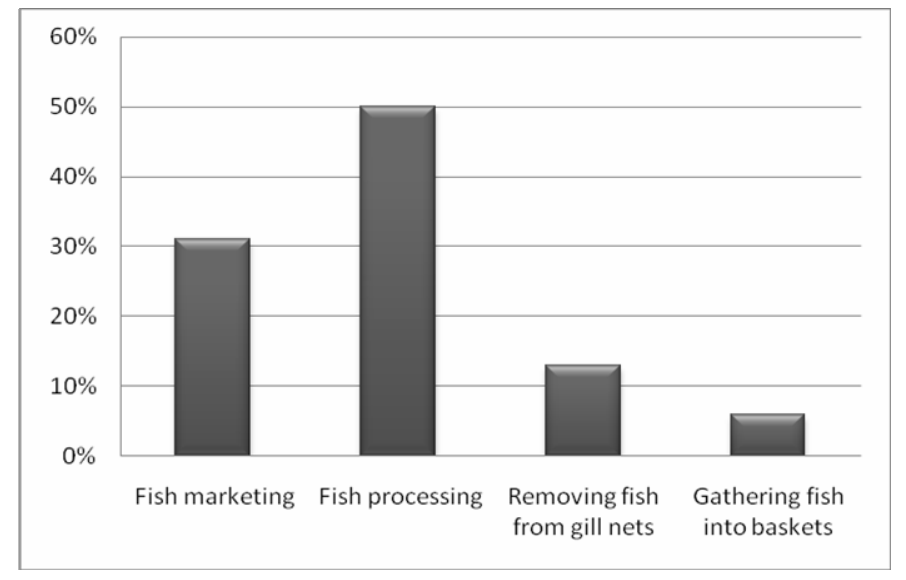

Figure 1. Percentages of women involved in different types of fishery related activities

About $50 \%$ of the women involved in fisheries were engaged in fish processing activities such as gutting, salting and sun drying of which about $70 \%$ were involved in gutting fish. They worked from about 7.00 a.m. to 1.00 p.m. and degut about 3 baskets of small pelagics, mainly Amblygaster sirm (Indian mackerel). These baskets which were made up of cane were parabolic in shape with a diameter of about $1.2 \mathrm{~m}$ at the mouth and a depth of about $0.3 \mathrm{~m}$ in the middle. Each of these baskets holds about 400 fish. The women involved in gutting were paid Rs. 100/= for one basketful of fish and thus they earned about Rs. 300.00 per day. Women involved in salting and drying fish worked from about 7.00 a.m. to 7.00 p.m. and each of them was paid Rs. 200.00 as the daily wage.

About $31 \%$ of the women were engaged in marketing the catch at the market place close to the landing site. Of these, about $15 \%$ sold large fish such as tuna and the others sold small fish such as grey mullets, carangids, clupeids etc. They purchased fish from the auction place at about 5.30 a.m. and marketing was over by about 9.00 a.m. Each of the women who sold large fish earned a profit of about Rs. 700.00 per day while each of those who sold small fish earned a daily profit of about Rs. 200.00.

About $13 \%$ of women were engaged in removing fish from small meshed gill nets operating mainly for clupeids. The main species removed were Ambygaster sirm and Sardinella spp. They worked from about 5.30 a.m. to about 7.30 a.m. and each of them was paid Rs. 100.00 per day.

About $6 \%$ of women were engaged in collecting fish into cane baskets to be carried to the auction place. They worked from about 5.30 a.m. to 7.30 a.m. and each of them was paid Rs. 50.00 per day if the catch was poor and Rs. 100.00 if the catch was good. 


\section{Income}

The mean monthly income of families where women were involved in fisheries was Rs. 9347.00 which was almost twice as the income of the families where women were not involved in fisheries (Table 1). This difference was statistically significant $(\mathrm{p}<0.05)$.

Table 1. Income levels of families where women were involved in fisheries and where women were not involved in fisheries

\begin{tabular}{|c|c|c|}
\hline & $\begin{array}{l}\text { Families where } \\
\text { women were } \\
\text { involved in fisheries }\end{array}$ & $\begin{array}{l}\text { Families where } \\
\text { women were not } \\
\text { involved in fisheries }\end{array}$ \\
\hline $\begin{array}{l}\text { Mean monthly income } \\
\text { (Rs.) }\end{array}$ & 9347 & 4712 \\
\hline Standard deviation & 661 & 237 \\
\hline Range (Rs.) & $8000-11000$ & $4200-5400$ \\
\hline $\mathrm{N}$ & 50 & 50 \\
\hline
\end{tabular}

\section{Socio-economics}

Results of the statistical analysis of socio-economic conditions of fishing families where women were involved in fisheries and where women were not involved in fisheries are summarized in Table 2. It was evident that ability to write and/or read among women and their involvement in fisheries were related to each other. The number of women who can write and/or read was significantly higher among those not involved in fisheries than those involved in fisheries $(\mathrm{p}<0.05)$ (Table 2$)$.

There was no significant relationship between women involvement in fisheries and children attending school $(\mathrm{p}>0.05)$. In both categories, the number of families where children were going to schools was higher than the number of families where children were not going to schools. Among the families where women were not involved in fisheries, there was not a single family with children of school going age who were not attending schools (Table 2).

Based on the physical nature, the houses of the fisher community could be divided into two groups, i.e., the houses with cemented floors and tiled or galvanized sheet roofs and the houses with un-cemented floors and thatched roofs. The floors of the latter type were made up of cow dung mixed with mud and the roofs were covered with thatched coconut fronds. There was no significant relationship with the type of house and the women involvement in fisheries $(p>0.05)$. In both categories, number of families living in houses with cemented floors and tiled or galvanized sheet roofs was higher than those living in houses with uncemented floors and thatched roofs. 
Table 2. Summary of statistical analysis of socio-economics of fishing families studied

\begin{tabular}{|c|c|c|c|c|}
\hline & $\begin{array}{c}\text { Number of families } \\
\text { where women were } \\
\text { involved in } \\
\text { fisheries }\end{array}$ & $\begin{array}{l}\text { Number of families where } \\
\text { women were } \\
\text { not involved } \\
\text { in fisheries } \\
\end{array}$ & $X^{2} / \mathrm{D}_{\max }$ & $\mathrm{p}$ \\
\hline Women were able to write and/or Read & 16 & 49 & $X^{2}=29.25$ & $<0.05$ \\
\hline Women were not able to write and/or read & 34 & 01 & & \\
\hline Children were going to school & 21 & 34 & $\mathrm{~d}_{\max }=2.07$ & $>0.05$ \\
\hline Children were not going to school & 09 & 00 & & \\
\hline $\begin{array}{l}\text { Houses with cemented floors and tiled/galvanized } \\
\text { sheet roofs }\end{array}$ & 42 & 48 & $X^{2}=0.26$ & $>0.05$ \\
\hline Houses with un-cemented floors and thatched roofs & 08 & 02 & & \\
\hline Houses with separate pipelines & 10 & 40 & $X^{2}=8.49$ & $<0.05$ \\
\hline Share the common tap & 40 & 10 & & \\
\hline Used LP gas or Kerosene for cooking & 16 & 43 & $X^{2}=16.0$ & \\
\hline Used fuel-wood for cooking & 34 & 07 & & $<0.05$ \\
\hline Houses with electricity & 29 & 48 & $\mathcal{X}^{2}=4.2$ & \\
\hline Houses without electricity & 21 & 02 & & $<0.05$ \\
\hline Roman Catholic & 49 & 50 & $\mathrm{D}_{\max }=.005$ & $>0.05$ \\
\hline Hindu & 01 & 00 & & \\
\hline Husband was a regular consumer of liquor & 38 & 08 & $\mathcal{X}^{2}=20.80$ & $<0.05$ \\
\hline Husband was an occasional consumer of liquor & 12 & 42 & & \\
\hline Wife was a descendant of a fishing family & 45 & 49 & $\mathcal{X}^{2}=0.08$ & $>0.05$ \\
\hline Wife was not a descendant of a fishing family & 05 & 01 & & \\
\hline
\end{tabular}


All households in the fishing community had access to pipe-borne water. However, majority of households where women were not involved in fisheries had their own water supply where as the majority of other category shared a common pipe by the roadside (Table 2). Statistical analysis indicated that there is a significant relationship between the mode of obtaining water and women involvement in fisheries $(\mathrm{p}<0.05)$.

The sources of energy used for cooking in the studied community were LP gas, kerosene and fuel-wood. Of the households where women were involved in fisheries, about $68 \%$ used fuel-wood and the rest used Kerosene for cooking. None of them used LP gas. Of the households where women were not involved in fisheries, about 12\% used LP gas and about $74 \%$ used kerosene for cooking. Only $14 \%$ of this category used fuel-wood. A significant relationship was noted between the source of energy used for cooking and women involvement in fisheries $(p<0.05)$.

A statistically significant relationship was observed between the availability of electricity in the household and women involvement in fisheries $(p<0.05)$. About $96 \%$ of the households where women were not involved in fisheries had electricity while only $58 \%$ of the households of the other category had this facility (Table 2 ).

Of the families studied, 99\% were Roman Catholics (Table 2). Other $1 \%$ was Hindus. There was no significant relationship between the religion and the women involvement in fisheries $(\mathrm{p}>0.05)$.

About $94 \%$ of the women of the studied community were descendants of fisher families (Table 2). There was no significant relationship between women involvement in fisheries and the fact that they were descendants of fishing families $(\mathrm{p}>0.05)$.

Husbands of all women in the studied community consumed liquor. However, in $76 \%$ of the families where women were involved in fisheries, husbands were regular consumers of liquor while the rest were occasional consumers. However, in families where women were not involved in fisheries, only $16 \%$ of husbands were regular consumers and the balance $84 \%$ were occasional consumers (Table 2). As such, there was a significant relationship between the involvement of women in fisheries and consumption of liquor by husbands $(\mathrm{p}<0.05)$. All the women interviewed denied that they consume liquor.

\section{Discussion}

In many fishing communities throughout the world, women help their husbands in fishery related activities. In the Philippines, women help their husbands to carry the boats or canoes into and out of water before and after each fishing trip (Siar et al. 1995). However, women in the fishing community studied are not involved in such activities. In some parts of the world, women actively catch finfish or shellfish (EC 2003, Fay-Sauni et al. 2008, FAO 2009, Kronen and Vunisea 2009, ICSF 2009). However, although in some parts of Sri Lanka, women are involved in catching finfish 
using beach seines (Saison et al. 2002), and shellfish using small traps, push nets (Personal observations) and gleaning (Kithsiri 1996), women in Wellaweediya fishing village where the present study was carried out were not involved in catching finfish or shellfish.

Women carry out pre-harvest activities such as net mending and net making in many artisanal fisheries throughout world (FAO 2009). In many coastal regions of Sri Lanka also women are engaged in pre-harvest activities such as net mending (Saison et al. 2002). However, in the fishing community studied, women were not engaged in such activities.

Women's role in fisheries in the Wellaweediya village is predominantly in the fish processing and marketing sector. It has been reported that majority of work force in the fish processing sector in the world consists of women (Williams 2001). In the studied community too, nearly $50 \%$ of women are engaged in fish processing activities that involve low grade unskilled jobs such as gutting, salting and sun-drying as reported by EC (2003) for many European countries. The income of women engaged in gutting was more or less equivalent to the daily wage of a male casual labourer. A male casual labourer working for 8 hours per day was paid only Rs. 350.00 during the period of this study. Therefore, it cannot be considered that the women labour of those involved in gutting fish in this area is exploited with gender discrimination. After 1.00 p.m., these women go back to their homes and spend the rest of the day with the family attending to day to day activities of the household. However, women labour of those involved in salting and sun-drying appears to be exploited by the employers with gender discrimination. In addition, they did not have much time to spend with their children and attend to day to day activities of the household.

Women labour of those involved in removing fish from gill nets also appears to be not exploited by employers with gender discrimination. However, the labour of those involved in gathering fish into transportation baskets appears to be exploited with gender discrimination when the catch is poor. This may be the reason for low number of women engaged in activities such as salting and drying, and gathering fish into transportation baskets.

In many countries throughout the world, women are involved in marketing the catch (EC 2003, FAO 2009, ICSF 2009). Compared with other fishery related activities marketing the catch appears to be the most lucrative activity as the women engaged in marketing earn the highest income for the time they spend. Most of these women were over 50 years of age and supported extended families. Husbands of some of these women were not employed and the entire family depended on the income earned by them. Many widows were also engaged in fish marketing. Therefore, it appears that economic demands have diversified their roles although they do not have changed there gender based household division of labour. Such complex demands in women's labour due to changing economies and social environments have been experienced in many countries (EC 2003, Sivoi 2004, Fay-Sauni et al. 2008). 
Income of the families where women were involved in fisheries was significantly higher than that of the families where women are not involved in fisheries due to the simple reason that both husband and wife were earning an income. Since the present study was carried out during the southwest monsoon period, the average income levels of both categories may be different from the values of the present study when the entire year is considered. Earning an income helps women to participate more actively in decision making in the household as observed in some rural households in Fiji where women are involved in fisheries. (Fay-Sauni et al. 2008). Although women involved in fisheries significantly contribute economically to maintain households in many parts of the world, their roles are reported to be unacknowledged (ICSF 2009).

Most of the fishery related activities in which women were involved in the studied community, require unskilled labour and even without an ability to read and/or write they can be employed. Low level of education has been reported among the women involved in fisheries in many countries throughout the world (FAO, 2009).

High literacy rate among women who were not involved in fisheries may be the reason for high rate of attending school of their children. However, it appears that although the percentage of illiterate women among those who were involved in fisheries was high, most of them try to educate their children and therefore the percentage of families with children who were not going to school was low in this category too.

Most of the fishers in the studied community, whether women were involved in fisheries or not, live in houses of fairly good condition. As such, there is no significant relationship between the nature of the house and women involvement in fisheries. However, majority of households where women were involved in fisheries were without electricity, used fuel-wood for cooking and shared a common tap by the roadside while majority of households where women were not involved in fisheries had electricity, used LP gas or kerosene for cooking and had their own pipeline. Therefore, the families where women were involved in fisheries, although earn a higher income appear to live in a more traditional way whereas the families where women were not involved in fisheries, although get a lesser income, appear to live in a more sophisticated manner. This may be due to high literacy rate among the women who were not involved in fisheries.

The region where this study was carried out was dominated by Roman Catholics. Therefore, no significant relationship was observed between the religion and women involvement in fisheries. Similarly, most families in this area were descendants of fishing families. Hence, no significant relationship between the descent and women involvement in fisheries was also noted. It appears that the drunkenness of husbands is low when women were not involved in fisheries. The reasons for this may be the low income and high literacy rate among women of these households. 
In conclusion, the present study indicates that the households where women were involved in fisheries earn a higher income than those where women were not involved in fisheries. However, even with the higher income, it appears that the living conditions of families where women were involved in fisheries were not better than those of the other category. This may be mainly due to low literacy rate among the women involved in fisheries. It may be necessary to carry out social development programme to enhance their living standards. Adult education programmes conducted with the help universities, non-governmental organizations and governmental organizations would be very useful in this regard.

\section{Annex I. Questionnaire used to gather information from fisher families}

1. General i. House Number

iii. Date of the Interview:

2. Personal Data of women

i. Age: ..........

ii. Marital Status: Single/Married/Widow/Separated $\backslash$

3. Number of members in the Family

Number of sons:

Number of daughters:

Others:

4. Religion:

\begin{tabular}{|l|l|l|l|}
\hline Member & Buddhist & Catholic & Other \\
\hline Father & & & \\
\hline Mother & & & \\
\hline Daughter(s) & & & \\
\hline Son(s) & & & \\
\hline
\end{tabular}

5. Literacy level of women

Ability to write: Good/Moderate/unable

6. Educational level of children (Indicate the number in the relevant cage)

Year 1-5

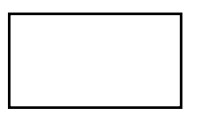

7. Nature of the house:

Year $6-11$

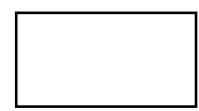

Tear $12-13$

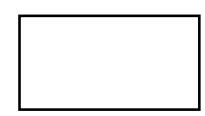

Not going to school

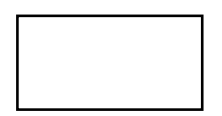

Floor: Cemented/Mud mixed with Cow-dung/terrazzo/Floor tiles/wood/.

Roof: Galvanized sheets/Roof tiles/asbestos/Thatched/. 
8 Water Supply:

\begin{tabular}{|l|l|l|l|}
\hline & Pipe borne & Well water & Other \\
\hline Drinking & & & \\
\hline Cooking & & & \\
\hline Bathing & & & \\
\hline
\end{tabular}

9. Source of Energy for Cooking: Fuel wood/Kerosene/LP Gas/Electricity

10. Electricity: Available/Not available

11. Whether involved in fishery related activities: Yes/No

If YES, the activities involved

\begin{tabular}{|l|l|l|l|}
\hline & Activity & YES & NO \\
\hline 1 & Catching fish & & \\
\hline 2 & Removing fish from the nets & & \\
\hline 3 & Collecting fish into baskets & & \\
\hline 4 & Marketing of the catch & & \\
\hline 5 & Gutting of fish & & \\
\hline 6 & Salting of fish & & \\
\hline 7 & Drying of fish & & \\
\hline 8 & Net Construction & & \\
\hline 9 & Catching prawns & & \\
\hline 10 & $\begin{array}{l}\text { Any other activity } \\
(\ldots \ldots . \ldots . \ldots . . . . . . . .)\end{array}$ & & \\
\hline
\end{tabular}

12. Consumption of liquor:

\begin{tabular}{|l|l|l|l|}
\hline & Regularly & Occasionally & Never \\
\hline Husband & & & \\
\hline Wife & & & \\
\hline Sons & & & \\
\hline Daughters & & & \\
\hline
\end{tabular}

13. Income of the family:

Husband:

Wife:

Son(s):

Daughters(s):

Others:

Total:

14. Problems faced by women: 


\section{Acknowledgements}

Financial support provided by the Asian Development Bank funded Science and Technology Personnel Development Project of the Ministry of Science and Technology through a scholarship awarded to the first author is gratefully acknowledged.

\section{References}

EC 2003.

Women in fisheries: an unnoticed role. Fishing in Europe 17: European Commission. Available from: http//ec.europa.eu/fisheries (Accessed on $20^{\text {th }}$ April 2009)

AOAC, 1995.

Official Methods of Analysis of Association of Official Analytical Chemists, $16^{\text {th }}$ edition. AOAC, Arlington, Virginia.

Bell, M.V, R.J. Henderson \& J. R. Sargent 1986.

The role of polyunsaturated fatty acids in fish. Comparative Biochemistry and Physiology 83B: 711-719.

Bell, J. G. 1998.

Current aspects of lipid nutrition in fish farming. In: Biology of Farmed Fish (K.D. Black \& A.D. Pickering eds), pp 114-145. Sheffield Academic Press, Sheffield.

Breder, C.M. \& C.W.Coates 1932.

A preliminary study of population stability and sex ratio of Lebistes. Copea, 3: 147-155.

Bromage, N.R. 1995.

Broodstock management and seed quality: general considerations. In: Broodstock Management and Egg and Larval Quality. (N.R. Bromage \& J.R. Roberts eds), pp 1-24. Black-well Scientific Publications, London.

Folch, J., M. Lees \& G.H. Sloane-Stanley 1957.

A simple method for the isolation and purification of total lipids from animal tissue. Journal of Biochemistry. 226: 497-509.

Halver, J.E. \& R.W. Hardy 2002.

Fish Nutrition. Academic Press, San Diego, California.

Henderson, R.J. \& D.R. Tocher 1987.

The lipid composition and biochemistry of freshwater fish. Progress in Lipid Research 26: 257-276.

Henderson, R.J. 1996.

Fatty acid metabolism of fresh water fish with particular reference to polyunsaturated fatty acids. Archives of Animal Nutrition. 49: 5-22

Higgs, D.A. \& F.M. Dong 2000.

Lipids and fatty acids In: Encyclopedia of Aquaculture (R.R.

Stickney ed), pp 476-496, Wiley, New York. 
Jobling, M., 1998.

Feeding and nutrition in intensive fish farming. In: Biology of farmed fish. (K.Black \& A.D. Pickering eds), pp 68-113. Sheffield Acad. Press, Sheffield.

Sargent, J.R., R.J. Henderson \& D.R. Tocher 1989.

The lipids. In: Fish Nutrition. (J.E Halver ed.), pp 154-219. Academic Press, San Diego, California.

Sargent, J.R., R.J. Henderson \& D.R. Tocher 2002.

The lipids. In: Fish Nutrition. (J.E Halver \& E. Hardy eds), pp 181257, Academic Press, San Diego, California.

Shoemaker, H.H. 1947

A laboratory study of fish populations. Transactions of American Fisheries Society 74: 351-359.

Tamaru, C.S., A. Harry \& P. Rostituto 1997.

Essential fatty acid profiles of maturation feeds used in fresh water ornamental fish culture. Hydrobiologia 36A: 265-268.

Tandler, A., T. Watanabe, S. Satoh \& K. Fukusho 1989.

The effect of food deprivation on the fatty acid and lipid profile of red seabream larvae(Pagrus major).Journal of Nutrition, 62: 349-361

Tocher, D.R., M. Agaba, N. Hastings, J.G. Bell, J.R. Dick \& A.J. Teale 2001. Nutritional regulation of hepatocyte fatty acid desaturation and polyunsaturated fatty acid composition in zebrafish (Danio rerio) and tilapia (Oreochromis niloticus). Fish Physiology and Biochemistry 24: 309-320.

Watanabe, T., T. Arakawa, C.Kitajima \& S. Fujita 1984.

Effect of nutritional quality of broodstock diets on reproduction of red seabream. Nippon Suisan Gakkaishi 50(3): 495-501.

Watanabe, T. 1993.

Importance of docosahexaenoic acid in marine larval fish. Journal of World Aquaculture Society 24: 152-161. 
